Interdisciplinary Studies of Complex Systems

No. 16 (2020) 87-101

(C) N. Demyanenko

https://doi.org/10.31392/iscs.2020.16.087

\title{
EDUCATIONAL INNOVATION STUDIES AS A COMPLEX SYSTEM
}

\author{
Natalia Demyanenko ${ }^{1}$
}

\begin{abstract}
Educational innovations are defined as a complex, selfrenewing systemic formation, dependent on changing social and educational priorities. The system of educational innovations has been developed taking into account the methodological and historical bases of its formation, defining the object and subject, classifications of innovations in education, criteria for selection and implementation of innovative experience, quality of innovative activities. Based on the analysis of scientific and theoretical approaches, the object of pedagogical innovation studies is the innovation process, conditions, methods and results of its implementation, the subject is the relationship between the efficiency of innovation processes and its determining factors, as well as ways of influencing these factors in order to increase the effectiveness of changes. The conceptual and categorical apparatus of educational innovations has been defined. The paper demonstrates diverse scientific views in the interpretation of its essence leading to the coexistence of different approaches in typologization and classification of pedagogical innovations. The scope, innovative potential, and scale of transformations are considered the main peculiarities of innovations. The empirical part presents the results of the scientific contextual Master's project "Innovative Experimental Educational Systems" implemented at the National Pedagogical Dragomanov University (Kyiv, Ukraine). The "quality of innovation activities" is considered a promising trend in the further study of educational innovation problems. Pedagogical universities are defined as the centres of forming students" ability to analyse, summarize, select innovative pedagogical experience, design and persistently introduce it into educational practice.
\end{abstract}

Keywords: educational innovations, system, experimental innovative experience, classification, selection, design, implementation of innovations, quality of innovative activities

\section{Relevance of the problem}

The globalization of the educational space gives rise to the search for a new educational paradigm. Innovations oriented generally to holistic, interdisciplinary, complex development and changing of the educational reality have always been one of the areas clearly reflecting paradigmatic changes. Today they are considered within a separate field of scientific knowledge - educational (pedagogical) innovation studies, integrating the ideas of innovation theory, philosophy, cultural studies, sociology, psychology, acmeology, creatology, for-

\footnotetext{
${ }^{1}$ National Pedagogical Drahomanov University, Kyiv, Ukraine. n.m.demyanenko@npu.edu.ua, https://orcid.org/0000-0002-5748-8292
} 
ming the basis for the development of innovative pedagogic and educational systems and their further implementation in modern education processes. The range of innovations is quite wide. They cover programs and standards, educational content, educational technologies, organization, and management of the educational environment. In this setting, the initiative belongs to a new type of a researcher - the teacher-experimenter-practitioner (in science) and the teacher/ educator-researcher (in practice), thus generating innovative educational experience. Its best models should be the basis for the education of future teachers who will educate new generations for the united Europe [1].

This places a priority on the task of exploring educational innovations as a complex, self-renewing systemic formation dependent on changing social and educational priorities. Therefore, we consider the system of educational innovation taking into account the methodological and historical bases of its formation, defining the object and subject, classifications of innovation in education, criteria for selection and implementation of innovative experience, quality of innovative activities.

State of development of the problem in theory and practice. The general theory of innovations dates back to the second half of the 19th - beginning of the 20th centuries and is consistent with the conceptual approaches of M. Weber, E. Fromm, O.Spengler. The changes related to the emergence of the theory of innovation and expansion of innovation activities were substantiated by D. Bell, J. Burnham, I. Wallerstein, J. Galbraith, P. Drucker, D. Meadows, T. Parsons, A. Peccei, A. Toffler. The first studies focused mainly on economic problems. The definition of cycles of innovations (J. Schumpeter) contributed to the activation of production processes in the 1920's. Since the 1930 's, the terms "innovation policy", "innovation process", etc. appeared in macroeconomics, resulting in the formation of the conceptual and categorical apparatus of innovation. It generated the science of innovation and further research, with the results reflected in the works of I. Ansoff, M. Barre, W. Brown, K. Oppenlander, K. Pavitt, E. Rogers.

Initially exploring economic, social patterns of creating and disseminating scientific and technological innovations, later - innovations in organizations and enterprises, in the late 1950's, innovation became an area of the interdisciplinary study of innovations. Approximately since that time, the rationale for educational innovation may be found in the works of K. Angelovski, H. Barnett, J. Bassett, D. Hamilton, N. Gross, W. Kingston, N. Lagerwey, M. Miles, A. Huberman, R. Havelock. Their papers symbolised the beginning of the internationalization of innovative educational processes. From our point of view, the reformist pedagogy of the early twentieth century with its deep interest in the child's personality, new solutions to education and upbringing served as a unique impetus for this. Anti-traditionalists (educators who opposed traditional theory and practice of education) sought ways of forming a personality throughout the whole period of childhood. The main approaches included pedagogy of positivism (G. Spencer), theory of "free education" (E. Key, F. Gansberg, L. Gurlitt, H. Scharrelmann, P. Lacombe, M. Montessori), experimental pedagogy (E. Meumann, E. Thorndike), pedagogy of action (W. A. Lay), pedagogy of pragmatism (J. Dewey), pedagogy of culture (W. Dilthey), theory of "labour school" and "civic education" (J. Bédier, H. Gaudig, G. Kerschensteiner, 
K. Woodward), pedology (E. Thorndike, S. Hall, A. Binet), theory of "new education" and "new schools" (C. Reddie, E. Demolins, A. Ferrière, P. Geheeb, H. Lietz) [9, p. 489]. The ideologists of new educational systems and technologies opened experimental educational institutions. This experience has made a significant impact on the formation of pedagogical innovations in the national education of the 20-30's of the last century, when in response to the acute needs of improving educational practice, the demand for social education ideas, our country hosted first experimental schools - educational institutions, implementing "a new pedagogical system, developed by a particular teacher or creative pedagogical team" [22, p. 8]. Experimental schools became known by the names of their creators (scientists or practitioners), with the creation of a pre-developed original conceptual project as their peculiarity.

The history of foreign and domestic education saw outstanding patterns of experimental schools. In particular, the Free School Community by H. Lietz, P. Geheeb (Germany) - boarding schools, acting on the principles of the child's free development and cooperation of citizens of a small society. The education was based on compulsory work and school choice. G. Kerschensteiner's Labour School (Germany), Ecole Des Roches School (France), A. Makarenko's colony and commune, S. Shatsky's school, P. Blonsky's school, which provided vocational training for schoolchildren, focused on work as Leipzig, L. Tolstoy's Yasnaya Polyana School considered inappropriate to teach a specific subject or trade. The interest in the student's development was decisive, so the time of their communication with the teacher was not limited. The School "for Life, through Life" (O. Decroly, Belgium) provided education and upbringing in close connection with nature, with support for the child's activities and freedom (centres of interest), close contact with the pupils" families. The School of Action (J. Dewey, USA) sought to bring learning closer to the lives and experiences of children, stimulating their natural development. The education process took into account the basic impulses of the child's natural growth: social (desire for communication), constructive (desire for movement in the game), research (craving for knowledge and understanding), expressive (desire for self-expression). Communication of children of all ages occurred mainly in extracurricular activities. It gave rise to "game school" (K. Pratt), based on the principle of using the game and the method of dramatization in the learning process; the "children's school" (M. Naumburg), guided by the motto "only by living, we learn" and giving preference to individual lessons; "Organic school" (M. Johnson), which focused on constructive classes in groups. Peculiarities of the above American schools included the desire to find new methods of teaching, attention to the interests of children, the study of individual characteristics of pupils, the development of their activity, the general tendency to practical and utilitarian learning and upbringing [3, p. 125-127].

To date, the experience of the following schools is still crucial: Waldorf School (R. Steiner's Pedagogical System, Germany), which was based on an anthropological understanding of the process of the child's development as a holistic interaction of physical and spiritual factors, solving the task of comprehensive personality development through intense spiritual activity; M. Montessori School (Italy) - a pedagogical system that envisaged the activity of children in a specially created environment (processes of self-discovery and exploration of 
the surrounding world took place in different age groups); S. Freinet's "School of Technology" (France), which grounded technologies of purposeful stimulation of pupils" intellectual and emotional activity, implemented new methods of education, development of useful social work at all stages of education and effective school self-government; educational institutions organized according to the "project method" (W. Kilpatrick, USA; B. Russell, UK), where the curriculum was structured in a set of interrelated experiments and pupils were given complete freedom of choice; the Dalton Plan-based schools (E. Parkhurst, USA), guided by the principles of the child's freedom, focused on the individual rhythm of learning, multi-age communication. This experience shows that educational innovations provide a link between traditions and design of future education. We agree with A. Boiko's opinion that the main thing is not the time of origin, but how the innovation serves the practice, improving the quality of education or upbringing, social goals and values. The new often reinterpreted the past and serves the development of the known, traditional, time-tested achievements of science grounded at a new level, in new social pedagogical realities and opportunities. Thus, the revival of productive scientific ideas, development of the latest achievements of science on their basis, enrichment with practice, as well as verification at a higher level of generalizations are also innovations requiring considerable creative efforts [2, p. 29]. Thus, innovations involve not only chronologically new ideas and experience but also those of outstanding educators of the past. The experience of the experimental schools of V. Sukhomlinsky (Pavlysh Village, Kirovohrad Region), I. Tkachenko (Bogdanivka Village, Kirovohrad Region), O. Zakharenko's family school (Sakhnivka Village, Cherkassy Region), etc., is still relevant and develops at new creative levels. The concepts and practices of such schools are usually different from the traditional ones and are often based on contrasting the existing system, its criticism and demonstration of the benefits of new approaches over the known ones.

Innovative pedagogical experience at the level of an independent scientific field was summarised in the works of well-known academic educators (Yu. Babanskyi, L. Hordin, V. Zagviazinskyi, V. Lazariev, M. Potashnyk, V. Slastonin, A. Khutorskoi, N. Yusufbekova, etc.). In particular, A. Khutorskoi [24, p. 21] called pedagogical innovations a science that studies the nature, patterns of emergence and development of pedagogical innovations, their connection with traditions of the past and future in relation to the subjects of education. In his opinion, pedagogical innovation studies explore the three-level process creation, learning and application of innovations. N. Yusufbekova interpreted pedagogical innovation studies as an independent branch of pedagogical science, studies about creation of pedagogical innovations, their evaluation, adoption by the pedagogical community and application in practice [25, p. 12]. N. Bordovska and A. Rean considered the progressive beginning in the development of educational institutions in comparison with the traditions and mass practice as the main parameters of pedagogical innovation studies. In their opinion, innovations in the education system are interrelated with changes in: the purpose, content, methods and technologies, forms of organization and management system; in the style of pedagogical activity and organization of educational and cognitive process; in the system of control and assessment of 
the level of education; in the financing system; in teaching and learning materials; in the system of educational work; in the curriculum and academic programmes; in the activity of teachers and students [3, p. 123].

\section{Object and subject of educational (pedagogical) innovation studies}

The development of pedagogical innovation studies as a scientific filed led to a search in determining its object and subject. For example, in V. Lazarev's opinion the object of pedagogical innovation studies is an innovative process, conditions, methods and results of its implementation, the subject is the relationship between the efficiency of innovation processes and factors determining it, as well as ways of influencing these factors in order to increase the effectiveness of changes [ 14, p. 16]. A. Khutorskoi expressed the opinion that the object of pedagogical innovation studies cannot be limited only by the innovation process, as it covers other processes and phenomena characteristic for innovations [24, p. 33], and therefore, the object of pedagogical innovation studies is the process of emergence, development and learning of innovations in the education of pupils, students, contributing to the progressive changes in the quality of their education, the subject is a set of pedagogical conditions, tools and laws associated with the development, implementation and adoption of pedagogical innovations in educational practice. A. Khutorskoi was the first to introduce in the subject of pedagogical innovations a system of relationships arising in innovative educational activities aimed at developing a personality of subjects of education - students, teachers, administrators [24, p. 14-15].

Conceptual categorical apparatus of educational innovation studies. The phenomenon of educational innovation has been researched and continues to be developed by the leading Ukrainian scientists, including M. Antonets, A. Boiko, L. Bondar, I. Dychkivska, N. Ditchek, O. Ihnatovych, V. Kurilo, V. Palamarchuk, O. Popova, O. Savchenko, O. Sukhomlinskaia and others. The concepts "innovation" (Latin innovatio - update, change) as "the introduction of the new, modernized" [18, p. 261], "the deliberate introduction of a particular innovation into the existing practice, resulting in positive changes and necessary effects achieved" [23, p. 255] serve the basis for the scientists to substantiate the concepts: "innovative", "innovation", "teacher-innovator", "pedagogical innovation", "innovative pedagogical activity", "pedagogical technology", "advanced (model) pedagogical experience", "introduction of pedagogical experience" [5, p. $19-26 ; 6$, p. $66-75 ; 11$, p. 94-104].

Thus, analysing the processes of pedagogical innovations, V. Palamarchuk differentiates the concepts "novation" and "innovation'. A novation is a result (product) of creative search of a person or team, which opens a fundamentally new phenomenon in science and practice, an innovation is a result of generation, formation and implementation of new ideas. Implementation of new ideas is a sign to distinguish an innovation from a novation itself: if teachers discover a fundamentally new idea, they are novators, if they transform a scientific idea into practice - innovators. According to V. Palamarchuk's approaches, "pedagogical innovations are the result of creative search for original, nonstandard solutions to different pedagogical problems" [19, p. 59]. 
O. Sukhomlynska comments on the concept of "innovative" from two points of view. First, it is "a process of introducing something new, something that was absent in the activity of other educational institutions, which may also concern the content of education, and especially the forms, means and methods of education and upbringing" $[17$, p. 7]. She proposes to refer such innovations to the best pedagogical experience. Second, a novation is "a fundamentally new approach to defining the general pedagogical conditions of an institution based on a new idea, which fundamentally alters the philosophy of the institution itself or gives birth to a new philosophy of education, shapes a new type of organization, content, direction and forms of activity, implemented in system and integrated innovation programs "[17, p. 7]. In turn, I. Zaichenko understands "innovations" in pedagogical interpretation as new developments in the pedagogical system, updating, improvement of the course and result of the pedagogical process $[10$, p. 77]. According to N. Dichek, "if we interpret pedagogical new developments as a process of introducing a novation into educational practice, then a pedagogical innovation is the process of emergence, development and, most importantly, widespread introduction of pedagogical novations and new developments into the educational field." In her interpretation, "an innovative teacher" is "an author of new pedagogical systems, developer and implementer of educational novations and new developments" [7, p. 64]. A. Boiko views "innovative pedagogical activity" as a kind of pedagogical activity aimed at designing, creating, testing, implementing or disseminating the achievements of pedagogical science, technology, model experience. He notes that innovation can be of theoretical and practical importance, of educational and didactic nature. Based on the author's vision, "pedagogical activity" is a generic concept in relation to the concept "innovative activity", which being specific serves as a means of its improvement and successful implementation in modern conditions. In this case, "pedagogical innovations", by A. Boiko's definition, are understood in a narrow and broad sense. In the narrow sense, they are some achievements of pedagogical science, didactic and educational technologies, progressive experience that meets the needs of practice. In the broad sense, they may be considered a science of innovations in the field of pedagogical knowledge. In this sense, innovations are the result of pedagogical achievements (science or practice), system, process, technology, methodology, means of training and education, etc. [2, p. 26, 29].

\section{Classifications of educational innovations}

The diversity of scientific views in determining the nature of pedagogical innovations in their related scientific direction results in the coexistence of various approaches in typologization and classification of pedagogical innovations, indicating the need for further comprehensive study of this complex phenomenon and systemic understanding of its development. N. Yusufbekova proposes to classify innovations according to the following parameters: place of occurrence (in science or practice); time of occurrence (historical or contemporary); the degree of expectation, forecasting and planning (expected and unexpected, planned and unplanned); possibility of implementation (modern and old-style, easily and difficult to implement); field of pedagogical knowledge 
(didactic, historical and pedagogical); level of novelty (absolute and relative); degree of transformation of pedagogical processes (radical or partial changes); belonging to the pedagogical system (systemic and non-systemic); originality (original and unoriginal) [25, p. 84-87]. V. Lizinskyi identifies three types of innovations: random (artificial, brought in from outside, often declared from above, and usually doomed to failure), useful (relevant educational missions, unprepared, for an indeterminate purpose, and criteria that do not form one strong unit with the school system) and systemic (derived from the problem field with clearly defined goals and objectives, prepared, provided with the necessary means) [15, p. 80-83]. I. Zaichenko defines low (innovations that suggest a change in the form of unusual names and phrases); middle (imply a change of forms without involving the essence) and high (change of the whole system or its components) levels of the modern process of innovations. In his opinion, the most important areas of innovations in education include: 1) pedagogical system as a whole; 2) educational institutions; 3) pedagogical theory, 4) teacher; 5) those who study; 6) pedagogical technology; 7) content of education; 8) forms, methods, means; 9) management; 10) purpose, objectives, results $[10$, p. 80$]$. I. Dychkivska believes that in accordance with the peculiarities of innovative processes, pedagogical innovations cover the following theoretical blocks of concepts and principles: creation of something new in the system of education and pedagogical science; perception of the new by the social and pedagogical community; use of pedagogical innovations, and a system of recommendations for theorists and practitioners to learn about and manage innovative educational processes. The results of pedagogical innovative activity, in her opinion, are divided into pedagogical discoveries, pedagogical inventions, pedagogical improvements that can be rationally combined [8, p. 23-25]. The four main classifications of types of innovations in general and higher education are proposed by A. Rean. The first classification is based on the correlation of the new with the pedagogical process of a particular educational institution. Accordingly, the following types of innovations are distinguished: in the purpose and content of education; in the methods, means, techniques, technologies of the pedagogical process; in the forms and methods of organizing education and upbringing; in the activities of the administration, teachers and students. The second classification of innovations in the education system is based on the application of the sign of scale. There are the following modifications: local and single, unrelated; complex, interconnected; systemic covering the entire school or institution of higher education. The third classification is based on innovation potential. These are modifications of the known and accepted, related to improvement, rationalization, modification (of the curriculum, educational programme, structure); combinatorial innovations; radical changes. The fourth classification of innovations is based on the grouping of signs in relation to their predecessor. This approach includes innovations that replace or cancel previous ones, discover something or retro novations [3, p. 129-130].

Today, the fundamental pedagogical science offers complex organized systematization of pedagogical innovations. For example, A. Khutorskyi systematised them into ten main blocks. Each of them is formed taking into account certain parameters of pedagogical innovations (in relation to the structure of science, subjects of education, conditions of implementation, characteristics of 
innovations) and differentiates according to their own set of subtypes: 1) regarding the structural elements of educational systems: innovations in goal setting, in tasks, in content of education and upbringing, in forms, methods, techniques, teaching technologies, means of education and training, system of diagnostics, control, evaluation of results, etc.; 2) in relation to the personal formation of the subjects of education: in the field of development of certain abilities of students and teachers, in the sphere of development of their knowledge, skills, methods of activity, competences, etc.; 3) regarding pedagogical use: in the educational process, in the educational course, in the educational field, at the level of the teaching system, the educational system, in the management of education; 4) by the type of interaction of the participants of the pedagogical process: in collective education, in group teaching, in tutoring, coaching, family education, etc.; 5) in terms of functionality: innovations-conditions (provide updates to the educational environment, socio-cultural conditions, etc.), innovationsproducts (pedagogical tools, projects, technologies, etc.), managerial innovations (new solutions in the structure of educational systems and management procedures, ensuring their functioning); 6) by means of implementation: planned, systematic, periodic, accidental, spontaneous, occasional; 7) in accordance with the scale of distribution: in the activity of one teacher, at school, group of schools, in the region, at the national, international level, etc.; 8) in terms of socio-pedagogical importance: in educational institutions of a certain type, for specific vocational-typological groups of teachers; 9) in terms of innovative measures: local, mass, global, etc.; 10) by the level of anticipated modifications: corrective, modifying, modernizing, radical, revolutionary. In general, in this taxonomy the same innovation can have several characteristics and occupy a certain place in different blocks [12, p. 27-38]. Based on A. Khutorsky's classification, N. Postaliuk proposed the following original division of innovations: 1) depending on the functionality: innovations-conditions that provide for an effective educational process (new content of education, innovative educational environments, socio-cultural conditions, etc.); innovations-products (pedagogical means, technological educational projects); organizational and managerial innovations (qualitatively new decisions in the structure of educational systems and management procedures that ensure their functioning); 2) depending on the field of implementation or introduction: in the content of education; teaching technologies, sphere of educative functions of the educational system; in the structure of interaction of participants of the pedagogical process, in the system of pedagogical means; 3) in terms of scale and social and pedagogical significance: state, regional and subregional or local, intended for educational institutions of a certain type and for specific vocational-typological groups of teachers; 4) on the basis of the intensity of the innovation change or level of innovation. The last criterion allows distinguishing eight ranks or orders of innovations: zero order (regeneration of primary qualities of system or its element); first order (quantitative changes in the system with its constant quality); second order (regrouping of the system elements and organizational changes); third order (adaptation changes of the educational system to new conditions without going beyond the old model of education); fourth order (new solution or simplest qualitative changes in individual components of the educational system); fifth order (creation of "new generation" education systems with changes 
in all or most of the primary qualities of the system); sixth order (creation of "new kind" educational systems with qualitative changes of functional features and preservation of the system-forming functional principle of the system); the seventh order (a fundamental change in educational systems with a change in the basic functional principle of the system); of the eighth order (emergence of a "new kind" of educational (pedagogical) systems [21, p. 41-50]. The last three ranks in educational practice are extremely rare. They are characterized by truly systemic innovations and can claim the status of innovative educational systems.

\section{Novelty parameter in the typology of educational innova- tions}

It is natural that novelty is recognized as one of the most important parameters in grouping innovations. Thus, V. Polonskyi gives a gradation (level) of novelty, which shows the qualitative difference of the object from the previous ones: 1) construction of the known in another form, that is, actual absence of the new - formal novelty; 2) repetition of the known with insignificant changes; 3) clarification, concretization of what is already known; 4) addition of already known essential elements; 5) creation of a brand new object [20, p. 4-12]. According to N. Bordovska, the following factors should be taken into account in the process of development of the educational system: absolute novelty (no analogues and prototypes), relative novelty and pseudonovelty or so-called inventive trifles [3, p. 124]. N. Borytko considers innovative projects from the point of view of the novelty level as well, specifying the following changes: 1) individual elements, partial refinements, improvements, new details, development of new rules for the use of traditional means; 2) at the level of groups of elements, a combination of known pedagogical means, their combinations, clarification of the sequence of their application; 3) at the level of the whole system of pedagogical means, supplementing this system with new means, development of rules and technologies of their use, emergence of new functional capabilities of the system; 4) a radical change of the whole pedagogical system on a new paradigm basis. According to her justification, according to the novelty levels, programs and projects can be divided into labour-saving, inventive, heuristic and innovative [4, p. 105-111].

The systematic analysis of the above material allows us to rest upon the following main peculiarities of innovations: scope (content of education, methods, technologies, forms, methods, tools, management of education, etc.); innovative potential (modification; combinatorial; radical); scale of transformations (local; modular; systemic) [26, p. 31-37].

\section{Project activities to find and synthesize innovative educa- tional experience}

Today, the leading pedagogical universities in the country are laying the groundwork for innovative educational experience in the professional training of future teachers. Thus, the National Pedagogical Dragomanov University has implemented the scientific contextual project "Innovative experimental 
education systems'. The project included the following main stages: 1) preparatory - the Project implementation was preceded by integrated invariant and variational training courses of the Master's Educational and Professional Program 011 Educational, Pedagogical Sciences (Pedagogy of Higher School): "History of Educational Systems of Higher Education", "State Standards and Quality of Higher Education", "Pedagogical Technologies in Higher Education", "Educational Subject-Subject Teacher-Student Relations", "Training of Professional and Pedagogical Competence", etc., implemented using the tutorial technology of the individual support of professional and pedagogical training of a specialist. The teaching of theoretical courses was carried out together with on-the-job training programs and scientific pedagogical practice of undergraduates in the educational institutions of the city of Kyiv, research units of the National Academy of Pedagogical Sciences of Ukraine - institutes of pedagogy, higher education, pedagogical education and adult education; 2) theoretical and conceptual stage - discussion of general scientific approaches to the organization of the Project "Innovative Experimental Education Systems" began during the Fifth National Exhibition-Presentation "Innovation in Modern Education", Kyiv, KyivExpoPlaza, October 23, 2013 (Education2013, November 6-13-No. 47 (5586). Theoretical substantiation and conceptual design took place at the 3rd Morozi pedagogical readings "Master's degree in the Educational Space of the University" (2014) (round table "Educational Innovation in the World Practice of Master's Training", March 14, 2014 // The III All-Ukrainian Moroz Pedagogical Readings. Thematic session "Master's Degree in the Educational Space of the University": Program. K., National Pedagogical Dragomanov University, March 14-15, 2014) and the Fifth International Exhibition "Modern Educational Institutions - 2014" (round table of the Department of Pedagogy and Psychology of the Higher School of the National Pedagogical Dragomanov University and All-Ukrainian Public and Political Weekly "Education" "Introducing Pedagogical Innovations in the Educational Process of Higher Education", Kyiv, KyivExpoPlaza, March 20, 2014); 3) empirical stage - creative missions of the undergraduates were planned and organized, which involved meeting, interviewing, establishing productive interpersonal communication and cooperation with Ukrainian teachers - authors of innovative educational concepts, technologies, original methods, organizational and managerial models, their students and followers. These missions made it possible to study the unique authorial experience of fifteen educators: Svitlana Vasylivna Bielukha "Technology of Integrated Multidisciplinary Learning"; Marianna Ivanovna Bosenko "Technology of Change of "Pedagogical Process Phenomena"; Olha Mykhailivna Hnatiuk "Technology of Collegial Management"; Mykola Petrovych Huzyk "Combined System of Organization of Educational Process"; Zoltan Zoltanovych Zhofchak "Technology of Systematic Deepening of Musical Education"; Oleksandr Antonovych Zakharenko "Personally Oriented Educational System in the Family School"; Yanina Mykolaivna Ovsiienko "Technology of Aestheticization of Education and Upbringing"; Mykola Mykolavych Paltyshev "Step-by-step Educational System"; Liudmyla Ivanivna Paraschenko "System of Management of Development of the School Integrated Educational Environment"; Nadiia Stepanivna Pushkar "Project Training Technology"; Hanna Stefanivna Sazonenko "Acmeological 
and Activity Model of Organization of Educational Space"; Serhii Mykhailovych Sichka "System of Formation of National Consciousness of Pupils"; Anatolii Ivanovych Solohub "Technology of Creative Subject-Oriented Training"; Mykhailo Ivanovych Chemberzhi "Concept and Model of Comprehensive Music Education"; Viktor Fedorovych Shatalov "System of Intensive Training". Generalization and systematization of the innovative experience analysed in the framework of the Project made it possible to deduce its following typology: experimental schools - M.P. Huzyk, O.A. Zakharenko, L.I. Parashchenko; experimental pedagogical technologies - S.V. Bielukha, M.I. Bosenko, O.M. Hnatiuk, Z.Z. Zhofchak, Ya.M. Ovsiienko, M.M. Paltyshev, N.S. Pushkar, V.F. Shatalov; 3) experimental models of educational environment - H.S. Sazonenko, S.M. Sichko, A.I. Solohub, M.I. Chemberzhi; 4) design and implementation, to be discussed further.

\section{Selection criteria for educational innovations}

The basic principle in substantiating the working criteria for selecting achievements of model experience for their further implementation is the ratio of innovation and pedagogical practice. The criteria include: 1) relevanceimproving the practice of educational work; 2) time relevance - significance for the present; 3) humanity and focus on the personality - disclosure of the conditions to form humanistic values, to fulfil educational, cultural mission, to promote creative ability and self-affirmation; 4) the innovation readiness and the teacher's methodical preparedness for implementation (programs, textbooks, plans, methodological sheets, recommendations, guidance materials, articles, etc.); 5) continuity with the previous experience and consistency with general trends in the development of the national education system; 6) integrity - a combination of dialectics of the whole and the part; 7) harmonization - specific work on implementing innovations in accordance with the professional and personal qualities of each teacher, improving their competence; 8) efficiency in modern conditions and perspective of the result - awareness of the essence of the new in the specific innovation, taken for introduction (in comparison with existing technologies) [2, p. 160-170].

Scientific findings of A. Boiko, M. Burhin, A. Kopytov, N. Kolominskyi, V. Kraievskyi, M.Skatkin, V. Chepeliev served as a guide in structuring the process of introducing pedagogical experience, which allowed distinguishing its following stages: 1) selection and evaluation of the new; 4) psychological, theoretical and practical training; 5) reporting on the study results; 6) development and provision of methodological materials; 7) clarification of new tasks and demonstration of samples; 8) armed with knowledge and skills; 9) creating model experience; 10) control over implementation; 11) identification and promotion of experience; 12) operative, generalizing stage; 13) final, summary stage; 14) mass introduction [2, p. 179]. These ways to put research into practice ( $d i$ rect, when the findings, methods, recommendations are directly addressed to the teacher and can be used in appropriate conditions; indirect, according to which the study results are incorporated into theory in one form or another, enrich to some extent and even rebuild it and, becoming part of the theory, both influencing the practice) led to the development of a working scheme for 
the implementation of scientific developments in practice: 1) theoretical work with educators; 2) practical demonstration of means, methods and techniques of activity; 3 ) analysis and generalization of the teacher's own experience; 4) propagation it among colleagues [26;27].

Prospects for the study of educational innovation problems. Interviews with authors of exemplary pedagogical experience, pedagogical teams of educational institutions have showed obstacles to the dissemination of innovative educational activities, including: indifference to the introduction of innovations, even with the awareness of their usefulness; imitation of innovative activity; inconsistency of implementation results with expectations; refusal at the stage of implementation or further use of the introduced innovation, etc. Therefore, we consider it promising to study the problem of "the quality of innovative activity" - the relationship between the necessary, potentially possible and changes that are actually implemented in the educational system of an educational institution. Focusing on available scientific findings $[13$, p. 120; 14, p. 15-16], we distinguish three main parameters of the quality of innovation: 1) sensitivity to the objective needs for a change, i.e. the ability of the educational institution to identify problems in a timely manner; 2) sensitivity to development opportunities (implementation potential), which is understood as the ability to effectively use identified opportunities to improve a particular educational system; 3) creativity as an educational institution ability to innovate to improve activity. "Evaluation of the quality of innovative activity" as an integrated concept should include: analysis of the state of the pedagogical system and identification of its current problems (problematization); finding opportunities (ways) to solve problems; planning innovations; motivation of performers; implementation of changes (introduction); control and regulation of change processes. Accordingly, the stage-categorical scientific apparatus should be used in solving the problem: 1) "quality of problematization" - a characteristic of innovative activity of an educational institution, which reflects its ability to identify objective actual problems of educational activity and to adequately assess their importance; 2) "quality of search for development opportunities" - a characteristic of the ability of an educational institution to find innovations developed in the science or practice of other educational institutions, and to adequately assess the usefulness and possibility of their use in their own activities; 3) "quality of innovation planning" — a characteristic of the ability of an educational institution to set the goal of its development, corresponding to objective needs and available opportunities, and to develop a system of coordinated actions of the pedagogical team that ensure the effective achievement of this goal; 4) "quality of motivation" - a characteristic of the conditions available in an educational institution in terms of their ability to induce members of the teaching staff to engage in active and productive activities; 5) "quality of implementation (plan implementation)" — a characteristic of the ability of the staff of educational institutions to agree, coordinate actions in the process of change implementation, to efficiently overcome the tension of transformation and to responsibly fulfil the tasks [16, p. 25-32]. From our point of view, all these components of the "quality of innovation" collectively determine the ability of an educational institution to develop, motivating the research interest. 
Based on the studied scientific theoretical papers, revealed and generalized innovative experience of teachers - authors of innovative pedagogical experience, the teaching staff of the Department of Pedagogy and Psychology of Higher Education has developed (partly - improved) training courses aimed at preparing future educators for pedagogical innovations: "Educational systems" (university-wide), "Pedagogical innovations in higher education", "Scientific school and personalized experience in the world educational dimension", "Partnership communication in education", "Training of effective interaction in the educational process", etc. , which are part of the Master's educational and professional programs "Higher Education Pedagogy: and "Andragogy. Adult Education", Specialty 011 Educational, Pedagogical Sciences.

Master's programmes not only form an algorithm, but also understanding of the conditions for successful implementation of innovations in practice: 1) social pedagogical (high competence, social orientation of the teacher's activity, responsibility and strong awareness of professional functions, education throughout the life); 2) theoretical and practical (combination of conscientious work with innovative ideas of scientists, cooperation of scientists and practitioners, development of a system of increasing the theoretical level of participants of implementation in accordance with the implemented object); 3) scientific and methodological (provision of subjects of implementation with a set of instructional and methodological materials, compliance of methodological developments with the capabilities of a specific staff and individual teacher, systematically organized assistance to the subjects of implementation by management and methodological bodies); 4) moral psychological (orientation of practitioners on the personality, development of a sense of the new, imagination, creativity, moral support and participation in pedagogical search, reasonable combination of insistence on high standards with encouragement in the process of implementation, achievement of "self-movement" and self-formation of the personality) [2, p. 201-202; 27, p. 22-27].

\section{Conclusions}

Therefore, generalizing, constructing and implementing innovative pedagogical experience is not a simple and conflict-free process; there is a constant need to identify and overcome natural contradictions between the new and inappropriate modern educational development, to find optimal ways of introducing new approaches to solving educational problems. Hence, it induces the need to systematically inform future educators about findings and achievements in all fields of the organization of the educational process, taking into account local conditions and needs. It is further supported by the results of the creative and experimental master's project of the National Pedagogical Dragomanov University (Kyiv, Ukraine), which analysed the unique experimental experience of fifteen Ukrainian teachers and allowed: 1) deriving a typology of innovative experience (experimental schools, experimental pedagogical technologies, experimental models of educational environment); 2) justifying the selection criteria for educational innovations (relevance, timeliness, humanity and personality orientation, innovativeness and methodological readiness of the teacher for implementation, continuity with the previous experience and consistency 
with the general tendencies of development of the educational system, integrity, harmonisation and concretization in accordance with the professional and personal qualities of each teacher, efficiency in modern conditions and long-term results); 3) structuring the process of implementation of pedagogical experience, specifying its stages - from selection and evaluation of the new to creation of exemplary experience and mass introduction. The project showed that educational institutions should not only introduce students to the models of pedagogical innovations, the activity of experimental schools, but also to form their abilities to analyse, summarize, select innovative pedagogical experience, prepare for its purposeful introduction into educational practice.

\section{References}

1) Andrushchenk V. P. 2011. Svitanok Yevropy. Problema formuvannia novoho uchytelia dlia obiednanoi Yevropy XXI stolittia Kyiv : Znannia Ukrainy.

2) Boiko A. M. 2011. Uprovadzhennia pedahohichnoi innovatyky v praktyku vykhovannia: monohrafiia / Polt. nats. ped. un-t imeni V.H. Korolenka. Poltava : PNPU imeni V.H. Korolenka.

3) Bordovskaia N. V., Rean A. A. 2007. Pedagogika: uchebnoe posobie. SPb.: Piter.

4) Borytko N. M. 2001. Pedagog v prostranstvakh sovremennogo vospitaniia / nauch. red. N.K. Sergeev. Volgograd : Peremena.

5) Demyanenko N. M. 2014. Pedahohichna innovatyka: vid terminolohichnoho obgruntuvannia do kryteriiv uprovadzhennia. Problemy osvity / Instytut innovatsiinykh tekhnolohii i zmistu osvity MON Ukraiiny. Kyiv. 78.1. : 19-26.

6) Demyanenko N .M. 2014. Teoretychni zasady vprovadzhennia pedahohichnykh innovatsii u kontekstnu pidhotovku mahistriv. Pedahohichni nauky / Poltavskyi natsionalnyi pedahohichnyi universytet imeni V.H. Korolenka. 60 : 66-75.

7) Dichek N. P.2012. Poniattievo-terminolohichni osoblyvosti vyvchennia pedahohichnoho novatorstva. Osvitolohiia: Polsko-ukrainskyi/ukrainskopolsky zhurnal. Varshava-Kyiv: Kyivskyi universytet imeni Borysa Hrinchenka ; Vyshcha pedahohichna shkola Spilky polskykh uchyteliv. $1: 62-68$.

8) Dychkivska I. M.2004. Innovatsiini pedahohichni tekhnolohii. Kyiv : Akademvydav.

9) Zaichenko I. V. 2010. Istoriia pedahohiky. U dvokh knyhakh. Kn. 1. Istoriia zarubizhnoi pedahohiky. Kyiv : Vydavnychyi Dim "Slovo".

10) Zaichenko I. V.2006. Pedahohika. Kyiv : Osvita Ukrainy.

11) Ihnatovych O. 2013. Teoretyko-metodolohichni osnovy pedahohichnoi innovatyky. Navchannia i vykhovannia obdarovanoi dytyny. 2. : 94-104.

12) Innovatsii v obrazovanii: chelovekosoobraznyi rakurs. 2009. / pod red. A.V. Khutorskogo. Moskva : TSDO "Eidos". 
13) Lazarev V. S. 2008. Upravlenie innovatsiiami v shkole. Moskva : Tsentr Pedagogicheskogo obrazovaniia.

14) Lazarev V. S., Martirosian B. P. 2004. Pedagogicheskaia innovatika: obiekt, predmet i osnovnye ponyatia. Pedagogika. 4 : 11-21.

15) Lizinskii V. M. 2011. Modernizatsiia shkoly ili novaia shkola. Moskva : Pedagogicheskii poisk.

16) Martirosian B. P. 2008. Povyshenie kachestva innovatsionnoi deiatelnosti v obrazovatelnykh uchrezhdeniiakh. Pedagogika. 7: 25-32.

17) Narysy z istorii rozvytku novatorskykh navchalno-vykhovnykh zakladiv v Ukraini (kinets XIX-XX st.). 2010. / za red. O.V. Sukhomlynskoi, V.S.Kuryla. Luhansk: Vyd-vo DZ "LNU imeni Tarasa Shevchenka".

18) Nechvolod L. I. 2009. Suchasnyi slovnyk inshomovnykh sliv. Kharkiv : TORSINH PLIUS.

19) Palamarchuk V. F. 2005. Innovatsiini protsesy v pedahohitsi: pershoosnovy pedahohichnoi innovatyky. Kyiv : Osvita Ukrainy.

20) Polonskiy V. M. 2007. Innovatsii v obrazovanii: (metodologicheskii analiz). Innovatsii v obrazovanii. $3: 4-12$.

21) Postaliuk N. Yu. 1989. Tvorcheskii stil deiatelnosti: pedagogicheskii aspect. Kazan : Izd-vo Kazan. un-ta.

22) Savchenko O.Ya. 2008. Avtorska shkola. Entsyklopediia osvity / Akad. ped. nauk Ukrainy; holovnyi red. V.H. Kremen. Kyiv : Yurinkom Inter : $8-9$.

23) Filosofiia polityky: korotkyi entsyklopedychnyi slovnyk. 2002. / Natsionalna akademiia nauk Ukrainy ; Akademiia pedahohichnykh nauk Ukrainy; Kyivskyi natsionalnyi un-t im. Tarasa Shevchenka ; Avt.-uporiad.: V.P. Andrushchenko, M.I. Boichenko, V.S. Bakirov [ta in.]; za red. L.V. Huberskoho. Kyiv : Znannia Ukrainy.

24) Khutorskoi A. V.2008. Pedagogicheskaia innovatsiia: uchebnoie posobie dlia studentov vysshikh uchebnykh zavedenii, obuchayushchikhsia p. pedagogicheskoi spetsialnosti. Moskva : Akademiia.

25) Yusufbekova N. R. 1991. Obshchie osnovy pedagogicheskoi innovatiki. Opyt razrabotki teorii innovatsionnykh protsessov v obrazovanii. Moskva : NII teorii i istorii pedagogiki.

26) Demyanenko Nataliia. 2014. Pedagogic innovation: from terminological reasoning to justifying. Neperervna profesiina osvita: teoriia i praktyka. $1-2: 31-37$.

27) Demyanenko N.2015. Pedagogical innovation in the educational space of university. Science and Education a New Dimension. Pedagogy and Psychology. Budapest, III 26(50) : 22-27. 